\title{
BOARD GENDER DIVERSITY DAN BOARD EDUCATION DIVERSITY TERHADAP BANK-RISK TAKING
}

\author{
Fani Khoirotunnisa \\ Universitas Pembangunan Nasional "Veteran” Jawa Timur
}

\begin{abstract}
The benefit of gender and education diversity on the board of commissioners is a subject of the current debate. This research investigates board gender diversity and board education diversity on bank risk-taking in Indonesian listed banks. Using a sample of 40 Indonesian banks over a period from 2012 to 2018, we find that board gender diversity has a significant negative effect on bank risktaking. In contrast, the nationality diversity between bank's board members does not directly impact bank risk-taking. This study concludes that the more significant the proportion of women on the bank's board, the less risk the bank has.
\end{abstract}

Keywords : Board Gender Diversity; Board Education Diversity; Bank Risk-Taking

Correspondence to : fani.khoiro.mnj@upnjatim.ac.id

\begin{abstract}
ABSTRAK
Manfaat keberagaman jenis kelamin dan latar belakang pendidikan dewan komisaris menjadi topik perdebatan akhir-akhir ini. Penelitian ini mengkaji dampak dari keberagaman jenis kelamin dan latar belakang pendidikan dewan komisaris terhadap pengambilan risiko bank di bank-bank yang terdaftar di Indonesia. Dengan menggunakan sampel dari 40 bank di Indonesia selama periode dari 2012 hingga 2018, peneliti menemukan bahwa keragaman jenis kelamin dewan memiliki pengaruh negatif yang signifikan terhadap pengambilan risiko bank. Sebaliknya, perbedaan latar belakang pendidikan tidak berdampak langsung pada pengambilan risiko bank. Kesimpulan dari penelitian ini adalah semakin besar proporsi wanita dalam dewan komisaris bank maka semakin kecil tingkat pengambilan risiko bank.
\end{abstract}

Kata Kunci $\quad$ : Board Gender Diversity; Board Education Diversity; Bank Risk-Taking

\section{Riwayat Artikel:}

Received : 13 Juli 2020

Revised : 27 November 2020

Accepted : 04 Juni 2021

\section{PENDAHULUAN}

Tujuan utama suatu perusahaan yaitu memperoleh laba yang optimal. Untuk mencapai tujuan tersebut, manajemen perusahaan mencari berbagai cara dan melakukan berbagai upaya seperti mengambil proyek berisiko untuk mendapatkan laba yang maksimal. Keputusan tersebut didasari oleh adanya teori high risk, high return dimana 
semakin berisiko suatu proyek maka akan semakin tinggi pula laba yang akan dihasilkan. Sama halnya dengan industri perbankan, dimana setiap bank mencari strategi terbaik dan menyalurkan kredit sebanyak-banyaknya untuk memperoleh laba yang besar. Bank risktaking merupakan perilaku pengambilan risiko oleh manajemen bank guna meningkatkan keuntungan atau laba perusahaan. Risiko terbesar yang sering diambil oleh bank yaitu risiko likuiditas, dimana demi mendapatkan keuntungan sebesar-besarnya dari pendapatan bunga, manajemen bank akan gencar untuk memberikan kredit pada masyarakat sehingga akan meningkatkan risiko likuiditas bank. Risiko likuiditas sendiri merupakan risiko akibat ketidakmampuan bank untuk memenuhi kewajiban yang jatuh tempo dari sumber pendanaan arus kas dan/atau dari aset likuid yang berkualitas tinggi yang dapat diagunkan tanpa menggangu aktivitas dan kondisi keuangan bank.

Pengambilan risiko yang berlebihan oleh bank merupakan salah satu penyebab utama krisis moneter tahun 1998 dan krisis global tahun 2007-2009. Besarnya dampak yang dapat diakibatkan oleh pengambilan risiko bank yang berlebihan tersebut menyebabkan dibutuhkannya manajemen risiko bank yang baik. Manajemen risiko merupakan alat untuk melindungi organisasi dari setiap kemungkinan yang merugikan melalui suatu proses penilaian risiko yaitu mengidentifikasi risiko, menilai, dan mengevaluasi sehingga risiko tersebut dapat diminimalkan dan kegiatan usaha dapat berjalan dengan efisien. Pelaksanaan manajemen risiko di suatu organisasi tidak terlepas dari pelaksanaan prinsip good corporate governance (GCG).

Good corporate governance (GCG) adalah suatu proses dan struktur yang digunakan oleh organ perusahaan (pemegang saham/pemilik modal, komisaris, dewan pengawas dan direksi) untuk meningkatkan keberhasilan usaha dan akuntabilitas perusahaan guna mewujudkan nilai pemegang saham dalam jangka panjang dengan tetap memperhatikan kepentingan stakeholder lainnya, berlandaskan peraturan perundangundangan dan nilai-nilai etika (Sutedi, 2011). Good corporate governance menganggap bahwa sangat penting bagi dewan untuk memiliki keseimbangan keanekaragaman dalam berbagai aspek, seperti keterampilan, pengetahuan, dan pengalaman serta jenis kelamin dan keanekaragaman lainnya. Board diversity diperlukan untuk mendapatkan banyak sudut pandang dalam proses pengambilan keputusan dewan. Board diversity akan menumbuhkan kreativitas dan inovasi dengan mempertimbangkan berbagai macam perspektif (Carter et al., 2003).

Studi ini difokuskan pada pengaruh board gender diversity dan board education diversity terhadap bank risk-taking. Untuk keanekaragaman gender, penelitian sebelumnya menemukan hasil yang berbeda tentang keberadaan direktur perempuan dalam pengambilan risiko perusahaan. Hubungan positif ditemukan karena kurangnya pengalaman oleh direktur wanita di sektor perbankan Jerman (Berger et al., 2013). Sebaliknya, hubungan negatif ditemukan karena wanita cenderung mengambil risiko lebih sedikit untuk menghindari kegagalan (Mateos de Cabo et al., 2012). Mengingat bahwa dewan biasanya terdiri dari orangorang dengan tingkat pendidikan yang berbeda, maka dampak dari keanekaragaman tingkat Pendidikan pada risiko perlu untuk diteliti. Selain itu, hasil dari penelitianpenelitian sebelumnya juga masih belum jelas. (Bertrand \& Schoar, 2003) menemukan bahwa hubungan antara tingkat pendidikan dan risiko adalah positif sedangkan (Graham \& Harvey, 2001) menemukan hubungan negatif. Oleh sebab itu, bagaimana keanekaragaman gender dan tingkat 
pendidikan dapat memengaruhi risiko tetap menjadi pertanyaan terbuka.

Tujuan dari penelitian ini adalah untuk mengukur dampak keanekaragaman dewan dalam hal gender dan tingkat Pendidikan pada risiko bank di Indonesia. Indonesia dipilih untuk menjadi subjek penelitian ini karena tiga alasan. Pertama, semakin meningkatnya kesadaran dunia, khususnya Indonesia tentang kesetaraan gender. Kedua, sejauh yang diketahui peneliti, keanekaragaman gender yang berfokus pada perempuan sebagai komisaris masih sangat sedikit di bank-bank Indonesia. Ketiga, menarik untuk memeriksa bagaimana keragaman dewan di Indonesia mempengaruhi pengambilan risiko bank karena merupakan negara berpenduduk terbesar keempat di dunia.

Penelitian ini membuat tiga kontribusi terhadap literatur yang ada. Pertama, penelitian sebelumnya dalam topik ini sebagian besar diselesaikan di Eropa dan AS; dengan demikian, penelitian ini akan memberikan perspektif baru tentang bagaimana keragaman dewan mempengaruhi risiko di negara berkembang: Indonesia. Kedua, sebagian besar penelitian terutama dilakukan di perusahaan non- keuangan. Terakhir, sebagian besar studi di Indonesia meneliti hubungan antara keragaman dewan dan kinerja. Namun, masih sedikit penelitian yang dilakukan untuk melihat efeknya terhadap risiko.

\section{Bank risk-taking}

Bank risk-taking berhubungan dengan perilaku pengambilan risiko oleh manajemen bank untuk meningkatkan pendapatan dan keuntungan perusahaan. Secara keseluruhan, bank risk-taking dapat digambarkan oleh risiko default suatu bank yang dihitung dengan menggunakan z-score (Houston et al., 2010; Lepetit \& Strobel, 2013).

\section{Board gender diversity}

Poletti-hughes dan Briano-turrent (2019) menyatakan bahwa wanita membawa pengalaman profesional dan perspektif yang berbeda dibandingkan dengan pria, sehingga kehadiran anggota wanita dalam dewan komisaris akan mengarahkan pada tindakan yang lebih informatif dan strategis. Selain itu, wanita cenderung lebih konservatif daripada pria (Yang et al., 2019) dan lebih ketat dalam pengawasan dan kontrol (Frye \& Pham, 2017).. Ketiga hal tersebut pada akhirnya diharapkan akan menyebabkan penurunan pada risiko bank.

\section{Board education diversity}

Keanekaragaman dalam latar belakang pendidikan dapat memacu inovasi, memberikan pendekatan kreatif yang sangat dibutuhkan untuk pemecahan masalah dan bahkan mengungkapkan peluang yang sebelumnya tidak terlihat, sehingga diharapkan adanya keragaman tingkat pendidikan dalam dewan dapat mengurangi risiko perusahaan.

\section{METODE PENELITIAN}

\section{Hipotesis Penelitian}

Berdasarkan hasil dari penelitian-penelitian terdahulu yang telah dijelaskan, hipotesis penelitian ini adalah :

$\mathrm{H} 1$ : Board gender diversity berpengaruh signifikan terhadap bank risk-taking

$\mathrm{H} 2$ : Board education diversity berpengaruh signifikan terhadap bank risk-taking 


\section{Model Penelitian}

Bank risk-taking ${ }_{i, t}=\beta_{0}+\beta_{1} \mathrm{BGD}_{\mathrm{i}, \mathrm{t}}+\beta_{2} \mathrm{BED}_{\mathrm{i}, \mathrm{t}}$ $+\beta_{3}$ control $_{i, t}+\varepsilon_{, t}$ Dimana:

B0 : Konstanta Bank risk-takingi, $\mathrm{t} \quad$ : Tingkat risiko bank i pada tahun ke $\mathrm{t}$ BGDi,t : Keanekaragaman jenis kelamin dewan komisaris bank i pada tahun ke $\mathrm{t}$ BEDi,t : Keanekaragaman tingkat pendidikan dewan komisaris bank i pada tahun ke $\mathrm{t}$ $\varepsilon \quad$ : error

\section{Kerangka Pemikiran}

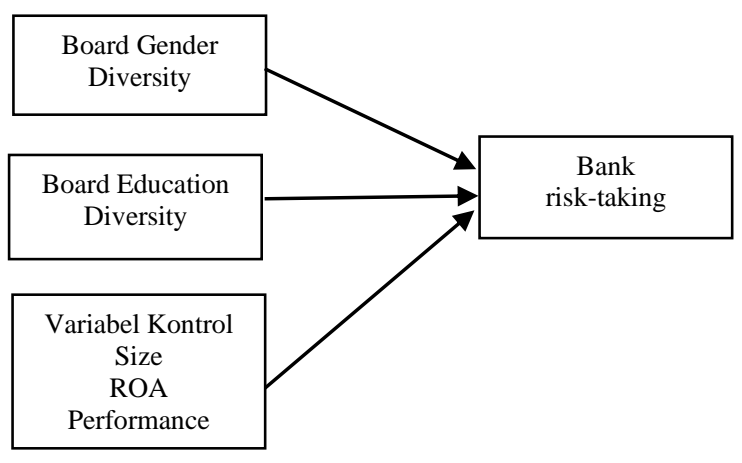

Gambar 1.

Kerangka Pemikiran

\section{Pendekatan Penelitian}

Penelitian ini menggunakan pendekatan kuantitatif, yaitu pendekatan penelitian yang menggunakan data-data terukur serta analisis data dengan prosedur statistik dengan tujuan mengukur variabel yang sedang diteliti dan menghasilkan kesimpulan yang dapat digeneralisasikan.

\section{Definisi Operasional Variabel}

Definisi operasional menggambarkan variabel-variabel yang digunakan dalam penelitian untuk menghindari ketidakjelasan makna. Adapun definisi operasional dari masing-masing variabel adalah sebagai berikut:
1. Bank risk-taking adalah tingkat risiko bank pada tahun ke t, yang diukur dengan z-score.

$z-$ score $_{i t}=\frac{R O A_{i t}+C A R_{i t}}{\sigma R O A_{i t}}$

Keterangan:

z-score ${ }_{i t}$ : z-score pada bank i tahun ke

$\mathrm{t}$

$\mathrm{ROA}_{\text {it }}$ : Return on assets pada bank i tahun ke t

$\mathrm{CAR}_{\text {it }} \quad$ : Capital adequacy ratio pada bank i tahun ke t

$\sigma$ ROAit : Standar deviasi return on assets setiap 3 tahun $\left(\mathrm{ROA}_{\mathrm{t}-2} ; \mathrm{ROA}_{\mathrm{t}-1} ; \mathrm{ROA}_{\mathrm{t}}\right)$ pada bank i tahun ke t.

Rasio ini adalah kebalikan dari risiko kebangkrutan. Oleh karena itu, nilai zscore yang lebih tinggi menggambarkan bank-risk taking yang lebih rendah.

2. Board gender diversity adalah keanekaragaman jenis kelamin para anggota dewan komisaris perusahaan pada tahun ke $\mathrm{t}$ yang diukur dengan menggunakan proporsi jumlah dewan wanita terhadap jumlah dewan komisaris secara keseluruhan.

3. Board education diversity adalah keanekaragaman latar belakang pendidikan para anggota dewan komisaris perusahaan pada tahun ke $\mathrm{t}$ yang diukur dengan menggunakan proporsi jumlah dewan dengan gelar minimal S2 terhadap jumlah dewan komisaris secara keseluruhan.

Dalam penelitian ini, penulis menggunakan beberapa variabel kontrol, antara lain :

1. Ukuran bank adalah besarnya bank yang diukur dengan logaritma natural total aset yang dimiliki oleh bank

2. Profitabilitas adalah tingkat keuntungan bersih yang diperoleh oleh bank dengan menggunakan 
P-ISSN 1693-9352 | E-ISSN 2614-820x

semua aset yang dimilikinya diukur dengan ROA.

$$
R O A_{i, t}=\frac{N I_{i, t}}{T A_{i, t}}
$$

Keterangan:

ROAi,t : Return on assets pada perusahaan i tahun ke $\mathrm{t}$

NIi,t : Laba bersih perusahaan i tahun ke $\mathrm{t}$

TAi,t : Aset total perusahaan i tahun ke $\mathrm{t}$

3. Kinerja bank adalah pertumbuhan pendapatan perusahaan pada tahun ke $\mathrm{t}$, yang diukur dengan rumus sebagai berikut :

$$
\text { Perf }_{i, t}=\frac{\left({\text { Operating } \left.\text { Income }_{i, t}-\text { Operating }_{\text {Income }}, t-1\right)}_{\text {Operating Income }} \text { I,t }-1\right.}{\text { Op }}
$$

\section{Sampel Penelitian}

Pengambilan sampel dalam penelitian ini menggunakan metode purposive sampling. Metode ini merupakan metode pengambilan sampel dengan kriteria tertentu sebagai berikut:

1. Bank yang terdaftar di Bursa Efek Indonesia

2. Perusahaan menerbitkan laporan keuangan tahunan yang berakhir pada 31 Desember pada tahun 2012-2018

3. Laporan keuangan disajikan dalam mata uang rupiah

Untuk mendapatkan sampel, peneliti menggunakan data yang bersumber dari laporan tahunan perusahaan perbankan yang terdaftar di Bursa Efek Indonesia dengan periode penelitian 2012- 2018.

\section{HASIL PENELITIAN}

\section{Uji Deskriptif}

Tabel 1 menunjukkan bahwa bank risk-taking yang diukur dengan z-score pada bank di Indonesia pada periode 2012 hingga 2018 menunjukkan rata-rata sebesar 98,923.
Nilai terendah untuk variabel $\mathrm{z}$-score adalah sebesar 0,111, sedangkan nilai tertinggi dari variabel tersebut adalah sebesar 887,5.

TABEL 1. Deskriptif Statistik

\begin{tabular}{lccccc}
\hline Variabel & $\mathbf{N}$ & Min & Max & Mean & Std. Dev \\
\hline Z-SCORE & 253 & 0,111 & 887,5 & 98,923 & 122,97 \\
\hline BGD & 253 & 0 & 0,5 & 0,111 & 0,1426 \\
\hline BED & 253 & 0 & 1 & 0,548 & 0,283 \\
\hline SIZE & 253 & 14,066 & 20,934 & 17,245 & 1,735 \\
\hline ROA & 253 & $-11,15$ & 5,42 & 1,155 & 2,307 \\
\hline PERF & 253 & $-11,833$ & 236,641 & 1,47 & 15,488 \\
\hline
\end{tabular}

Sumber : data olahan penulis

Rata-rata board gender diversity dan board education diversity masing-masing adalah sebesar 0,111 dan 0,548 yang berarti bahwa mayoritas anggota dewan komisaris perusahaan berjenis kelamin pria dan memiliki latar belakang Pendidikan minimal S2.

Berdasarkan tabel 1, variabel size yang ditentukan dari logaritma natural total asset mempunyai nilai rata-rata sebsar 17,245. Sedangkan, rata-rata ROA dan performance bank masing-masing sebesar 1,155 dan 1,47.

\section{Uji Multikolinearitas}

\begin{tabular}{|c|c|c|c|c|c|}
\hline & BGD & BED & SIZE & ROA & PERF \\
\hline BGD & 1 & & & & \\
\hline BED & 0,03 & 1 & & & \\
\hline SIZE & $-0,23$ & 0,34 & 1 & & \\
\hline ROA & $-0,07$ & 0,18 & 0,42 & 1 & \\
\hline PERF & 0,12 & 0,02 & $-0,07$ & $-0,03$ & 1 \\
\hline
\end{tabular}

TABEL 2. Matriks Korelasi

Sumber : data olahan penulis

Tabel 2 menunjukan bahwa tidak terdapat korelasi antar variabel independen dalam model regresi dalam penelitian ini karena tidak terdapat nilai korelasi antar variabel yang melebihi 0,8 . 


\section{Pengujian Hipotesis}

Berikut merupakan hasil pengujian hipotesis model regresi dengan menggunakan variabel dependen, yaitu bank risk-taking yang diukur menggunakan z-score, variabel independen, board gender diversity, board education diversity, dan variabel kontrol berupa ukuran perusahaan, profitabilitas, dan kinerja perusahaan.

TABEL 3. Hasil Analisis Pengaruh Board gender diversity dan Board education diversity terhadap Bank risk-taking

\begin{tabular}{lccc}
\hline \multicolumn{1}{c}{ Nama } & Koefisien & T-stat & Sig \\
\hline Konstanta & 4,9194 & 0,06 & 0,954 \\
\hline BGD & 146,817 & 2,67 & $0,008 * * *$ \\
\hline BED & $-10,706$ & $-0,38$ & 0,708 \\
\hline Size & 4,1985 & 0,81 & 0,418 \\
\hline ROA & 10,381 & 2,87 & $0,004 * * *$ \\
\hline Performance & $-0,5596$ & $-1,14$ & 0,256 \\
\hline $\mathrm{R}^{2}$ & 0,0718 \\
\hline \multirow{4}{*}{,$* * * * *$ significant at $\alpha$ of $10 \%, 5 \%, 1 \%$} \\
Sumber : data olahan penulis
\end{tabular}

Berdasarkan Tabel 3 hasil analisis model regresi menunjukkan bahwa board gender diversity berpengaruh positif signifikan terhadap z-score. Hasil ini menunjukkan bahwa semakin besar proporsi wanita dalam jajaran dewan komisaris, maka akan semakin rendah tingkat pengambilan risiko bank tersebut. Selain itu, ROA (profitabilitas) juga memiliki pengaruh positif signifikan terhadap z-score yang berarti semakin tinggi profitabilitas suatu bank, maka akan semakin rendah tingkat pengambilan risiko bank tersebut.

Hasil olah data menunjukkan bahwa board education diversity, ukuran dan kinerja bank tidak berpengaruh terhadap bank risktaking karena memiliki nilai signifikansi lebih besar dari 0,05 .

\section{PEMBAHASAN}

Penelitian ini menunjukkan bahwa adanya anggota dewan komisaris wanita umumnya akan meningkatkan pengawasan dewan. Selain itu, wanita juga lebih konservatif dibandingkan pria dalam pengambilan risiko (risk-averse). Sehingga semakin besar proporsi wanita dalam dewan komisaris maka akan menurunkan bank risktaking. Temuan ini sejalan dengan hasil penelitian Gulamhussen \& Santa (2016) yang menyatakan bahwa board gender diversity berpegaruh negatif terhadap bank risk-taking. Selain itu, studi ini juga menemukan bahwa keanekaragaman tingkat Pendidikan para anggota dewan komisaris tidak memiliki pengaruh yang signifikan terhadap bank risktaking. Hal ini mungkin dapat terjadi karena tingkat Pendidikan seseorang tidak selalu menggambarkan kemampuan dan pengalaman seseorang dalam bidang pekerjaan. Sehingga perbedaan tingkat Pendidikan dewan komisaris tidak memiliki hubungan yang signifikan dengan pengambilan risiko bank.

\section{KESIMPULAN}

Simpulan yang dapat diambil dari penelitian ini adalah :

1. Board gender diversity berpengaruh positif signifikan terhadap $z$-score. Karena $z$-score berhubungan terbalik dengan bank risk-taking, maka dapat disimpulkan bahwa bank dengan proporsi anggota dewan komisaris wanita yang semakin besar cenderung akan lebih menghindari risiko dan lebih memperketat pengawasannya.

2. Board education diversity tidak berpengaruh signifikan terhadap bank risk-taking.

3. Ukuran bank tidak berpengaruh signifikan terhadap bank risk-taking.

4. Kinerja bank tidak berpengaruh signifikan terhadap bank risk-taking.

5. Profitabilitas (ROA) berpengaruh positif signifikan terhadap $z$-score. Karena $z$-score berhubungan terbalik dengan bank risk-taking, maka dapat disimpulkan bahwa bank dengan 
tingkat profitabilitas yang semakin besar cenderung akan mengambil lebih sedikit risiko.

\section{DAFTAR PUSTAKA}

Berger, A. N., Kick, T., \& Schaeck, K. (2013). Executive board composition and bank risk taking. Journal of Corporate Finance.https://doi.org/10.1016/j.jcor pfin.2013.11.006

Bertrand, M., \& Schoar, A. (2003). Managing with style: The effect of managers on firm policies. The Quarterly Journal of Economics, 118(4), 1169-1206.

Carter, D. A., Simkins, B. J., \& Simpson, W. G. (2003). Corporate governance, board diversity, and firm value. Financial Review, 38(1), 33-53. https://doi.org/10.1111/15406288.00034

Frye, M. B., \& Pham, D. T. (2017). CEO Gender and Corporate Board Structures CEO Gender and Corporate Board Structures Abstract.

Graham, J. R., \& Harvey, C. R. (2001). The theory and practice of corporate finance: Evidence from the field. Journal of Financial Economics, 60(2-3), $187-243$ https://doi.org/10.1016/S0304405X(01)00044-7

Gulamhussen, M. A., \& Santa, S. F. (2016). Female directors in bank boardrooms and their in $\mathrm{fl}$ uence on performance and risk-taking is. Global Finance Journal, 28(January 2010), 10-23. https://doi.org/10.1016/j.gfj.2015.11. 002

Houston, J. F., Lin, C., Lin, P., \& Ma, Y. (2010). Creditor rights, information sharing, and bank risk taking. Journal of Financial Economics, 96(3), 485512.

https://doi.org/10.1016/j.jfineco.2010 .02 .008

Lepetit, L., \& Strobel, F. (2013). Bank insolvency risk and time-varying $\mathrm{Z}$ score measures. Journal of International Financial Markets, Institutions and Money, 25(1), 73-87. https://doi.org/10.1016/j.intfin.2013.0 1.004

Mateos de Cabo, R., Gimeno, R., \& Nieto, M. J. (2012). Gender Diversity on European Banks' Boards of Directors. Journal of Business Ethics, 109(2), 145-162. https://doi.org/10.1007/s10551-0111112-6

Poletti-hughes, J., \& Briano-turrent, G. C. (2019). International Review of Financial Analysis Gender diversity on the board of directors and corporate risk : A behavioural agency theory perspective. International Review of Financial Analysis, 62(August 2018), 80-90.

https://doi.org/10.1016/j.irfa.2019.02. 004

Sutedi, Adrian. (2011). Good Corporate Governance. Jakarta: Sinar Grafika.

Yang, P., Riepe, J., Moser, K., Pull, K., \& Terjesen, S. (2019). Women directors, firm performance, and firm risk: A causal perspective. Leadership Quarterly, 30(5), 101297. https://doi.org/10.1016/j.leaqua.2019. 05.004 